\title{
CHANGE AND EVOLUTION OF MIHRAB MOTIFS
}

\author{
Sara Azizi \\ Department of Architecture and Design, Islalmic Azad university, Iran \\ saraazizi14465@gmail.com
}

\begin{abstract}
In this study, at first we tried to provide the meaning and concept of the Mihrab in dictionaries and also its place in mystical literature. In the next stage, different classifications and theories about the origins of the Mihrab and the origin of this design was examined and in any case the necessary explanations were provided; For example, on the Mihrab in Islam after stating the theory, topics such as the initial altars, altar design in the mosques, the Muslim world's most famous altars, altar in Islamic architecture and ... are mentioned; Or on the theory of Mihrab and Mehrabeh after explaining the relationship between the Mihrab with Mehrabeh in Mehri religion, about the form of Mehrabeh, allegory of killing cattle, Iran's Mehrabeh have been discussed. After investigating the relationship between Iranian nomadic saltshakers with the Mihrab design, various Mihrab designs with photos of it were described, and in the end, in addition to reviewing the symbol of Mihrab and prayer rug carpets, some examples of Mihrab carpets in the carpet museum were investigated.
\end{abstract}

Keywords: Mihrab / Mehrab / Mehri religion / Mithraist Regulation / evolution of designs / prayer rug designs

\section{MIHRAB MOTIFLERIN DEĞișíKLİĞí VE EVRIMI}

\section{ÖZ}

Bu çalışmada, ilk olarak biz de anlam ve Mihrab kavramını sözlüklerinde ve mistik literatürde yeri sağlamak için çalıştı. Bir sonraki aşamada, farklı sınıflandırmalar ve Mihrab ve bu tasarım kökeni kökeni hakkında teoriler incelenmiş ve her durumda gerekli açıklamalar verilmiştir; Örneğin, İslam'da Mihrab üzerinde teori belirten sonra, örneğin ilk sunaklar, sunak camilerde tasarım, Müslüman dünyanın en ünlü sunaklar, sunak İslam mimarisinde ve ... bahsedilmektedir gibi konular; Veya Mehrabeh şeklinde, sığır öldürme alegori hakkında Mehri din Mehrabeh ile Mihrab arasındaki ilişkiyi açıklayan sonra Mihrab ve Mehrabeh teorisi, İran'ın Mehrabeh tartışılmıştır. Mihrap tasarımı ile İran göçebe yapımıyla sürmektedir arasındaki ilişkiyi araştıran sonra, o fotoğrafları ile çeşitli Mihrab tasarımlar Mihrab ve seccade halıların sembolü, halı müzesi Mihrap halı bazı örnekler gözden ek olarak, tarif, ve sonunda bulundu incelenmiştir.

Anahtar Kelimeler: Mihrap / Mehrab tasarmlar / seccade tasarımlarl / Mehri din / Mithraici Yönetmeliği / evrimi

\section{INTRODUCTION}

Traditional design of Iran is basically formed before history i.e. before the appearance of handwriting. We know man has begun design from the caveman stage, a period that he used simple and rough stones as tools, but the man of this period has important cultural achievements that has affected his designing. The period of the Neolithic, Bronze to Iron each for man, or at any time the man has certain achievements for us that should be 
recognized, because in each of the periods in terms of social and economic conditions of people, a bunch of designs is created. Aside from this, man's belief in any period of time causes to emergence of designs, which should to pay them. Iran's major principles of traditional design is religious, but before reaching that basis it should be said that even the first designs which the man drew has also the religious basis, ie is mainly magical. Any belief in an external force of nature or metaphysics is a foundation for religion, even though today we do not take into account those beliefs as part of religious. For example, sorcery is quite religious and incidentally all early drawings of human have also magical Foundation, They have drawn buffalo or deer on cave walls to shoot it, because the man believed that if he capture the image of something, he will capture that. The place of arrow on the paintings in caves is not few. The design of mountains, water, religious dance, symbols of water, plant, animal and faces have accumulated major part of ancient artifacts -like ceramics-. Even later and in advanced civilizations the religious designs on a variety of vehicles of human life can be seen. For example, we see the image of a jug was discovered in Marv and Siavash mourning rite, which is in fact the rite of mourning of the God of vegetal, can be seen on it. Of course also purely decorative designs from a long time can be seen on vehicles. (1)

\section{HISTORICAL BACKGROUND OF RESEARCH}

In the book, Research on the carpet of Iran by well-known and successful researcher of the country, Mr. Zhuleh, materials are mentioned on the Mihrab carpet including the Classification of the origin of the Mihrab carpets that, in this study, the Classification is based on it. With the exception of the churches that it is believed because of the low probability of honesty of this theory they have not referred it. in other books there are no comprehensive explanation on the Mihrab carpets, and only during the division of the Iranian carpet designs a brief mention has been made to Mihrab designs such as: "Nain carpets" and "big carpet designers," from Publications of Ms. Sour Israfil and "Principles of traditional design in Iran " written by Mr. Ali Hosouri. Or in the books carpet of areas, examples of Mihrab carpet of that area is depicted, such as: carpet Sarough (Ms. Sour Israfil), Iranian carpets (Sicily Edwards), Pictorial rugs (Parviz Tanavoli), Iranian carpet - a set of carpets in carpet Museum of Iran - (Ms. Leila Dadgar) and many other books.

\section{RESEARCH HYPOTHESIS}

According to various theories about the origin of the Mihrab designs that in the third chapter we explain in detail about it; In this study, we intend to prove in addition that there is no contradiction between the ideas presented by researchers but also a direct relationship exists between them; For example, it may that Mihrab design at the beginning -as we will refer in the third chapter- have been taken from animal skins, which later have been transferred to form vault like the Mehrabeh of Mehri regulations and have been transferred from there to churches and mosques. What is important in the issue of the origin of the Mihrab design is that the form of alter has remained eternal because of its holiness such an extent that by changing rites and practices, this form which has a specific state of holiness to humans is still survive in Architecture, carpet and other decorative arts, particularly

religious decorative arts.

The meanings of Mihrab in Farsi and Arabic dictionaries: the mihrab was taken from the verb Harb that its infinitive was Harb and Mihrab. According to Ibn Manzur: it is in fact warlike man and Mohreb and the Mihrab, means a person who is very warrior, and it is said Mohreb and the Mihrab, means a person who has the courage and warlike.

\section{GENERAL CATEGORIZATION ABOUT THE ORIGIN OF MIHRAB MOTIFS}

1. Some have considered it as a conception of the view of animal skin which was the first ground cloth of human and some have likened it to the caves entrance of the early human settlement. (12)

2. A group have addressed to Lexical meaning of Mihrab -the holy place with curved Arch in mosques, where the imam stand during prayer-. Thus, given the similarity of Mihrab 
designs on small rugs which is generally proportional to the size figure of one prayer, it is said that the source of Mihrab designs should be searched in the altar of mosques.

3. A group considers the origin of the altar in the trough of churches

4. Doctor Ali Hosuori believes that the history of this design should be searched in ancient times and the name of this design led us to study its source. He believes mehrabi design (not an altar with this writing Mihrab) as its name implies, is rooted in the Mehr Regulation and its beginning should be searched in that history.

Mehrab essentially means the temple of Mehri. As Sardab means cold room or Garmabeh means warm space. Mehrab, in fact, is where Mehr (from creatures of Ahura and protective god of covenant and the angel of light and lighting) kill the cow that the place has arched vault.

\section{MIHRAB ON ISLAM AND ITS RELATIONSHIP TO THE MEHRABEH}

We can discuss On the Mehrabeh from other angles and landscapes, including on lexical and functional similarity of "Mehrabeh" and "mihrab" where there are many challenges, although most researchers believe that there is a link between these two terms. So that doctor Parviz Varjavand, well-known researcher says: in terms of Mehrabeh, basket-handle arch of roof, creates a place where "Mehr" has put dagger on the neck of the cow. We see this structure in many altars of mosques of Iran, I.e. in these altars, an indent in the South region (the direction of head) has been created and there we saw that half the arc there is in Mehrabeh. As a result he knows the mihrab word from the word Mehrabeh. However, some people believe that the mihrab in Islamic mosques was the war place has no relation with Mehrabeh. (17)

\section{THE MOST FAMOUS ALTARS MUSLIM WORLD}

1. Al-Aqsa Mosque that in heravi narration, Umar ibn al-Khattab has imposed it.

2. Mosque in Kufa that goes back to Uthman ibn Affan years 26-28 AD.

3. Mosque Prophet (PBUH) in Medina that its time based on historical texts goes back to the era of Uthman ibn Affan.

4. Central mosque of Damascus that goes back to the caliphate of Muawiyah.

5. Altar of Aqaba ibn Nafi in Central Mosque Kairouan which was built in 50 AD.

6. Mosques of Amro in Fustat before the year 79 or $80 \mathrm{AD}$ or before the era of Karra ibn Sharik. (20)

\section{MIHRAB IN ISLAMIC ARCHITECTURE}

The Mihrab of mosque, an arch facade that indicates the direction of worshipers, is in fact, little of the Mihrab (Apse) of the Christian Church that has (Alter) in itself. Mihrab (Apse) of the Christian Church is reminiscent of deep and large arch of Greek-Roman temples, ritual statues was there or in the recent palaces of the Old Roman placed Empire in itself. This arch facade even in the context of a mosque has always retained memories and remaining of his primary function. Because, the imam of Friday prayers is placed in it to lead the worshipers. The fact that part of the task of Khalifa was that act like Imam (Friday). (21) Professor Pope said: "In the early images of the mountain this entrance with a port was made dual that is the symbol of the sacred place. Heavenly forces are in contact with the ground there. The first temples of ziggurats, the niche that is the door to the spiritual world has been shown with large external ports.

\section{SIMILARITIES AND DIFFERENCES BETWEEN SANCTUARY OF CHURCHES AND MOSQUES}

Islamic encyclopedia about the origin of the altar writes that orientalists and art historians have cited two sources for the altar, one, church Christians dents and the other Buddhist temple. Henri Lehmann said: "simply the altar is made in imitation of Christianity." But Doctor Ahmad Fekri Iraqi rejected this theory and in this regard said, "Apse of mosques, is small, the corner that is enough for bowing and prostration of Imam in it and the altar of churches is large for doing religious rituals and comfortable commuting. The altar is higher than the church, while the Apse is at the same level with the ground as well as the altar for 
Christians is holy and glorious. While Muslims consider Apse one of the components of the Mosque and Ibn al-Hajj stated that the Apse is the lowest component of the mosque, he said, "He who is afraid to sleep in the mosque, then he must sleep in Apse, because it has the lighter parts of the mosque. "

\section{MEHRABEH IN MEHR RITUAL}

Mehrabeh means actually the position and the Temple of Mehr or the sun. in the term "Mehrabeh" the name Mehr is the first component that sometimes is one with the sun and takes the suffix "Abeh, Aveh" that in words Garmabeh and Sarmabeh and seems a part of it. Abeh or Aveh means a roofed place with arched ceilings and beat arches that the Mehrabeh was building to this type, and the roof of bathrooms and basements to live had such a structure. As a result, Mehrab basically means the temple of Mehri.

\section{COLOR AT THE APSE}

Although Muslim architects sees visual sense of color, but seeks other concepts behind color and coloring. Muslim architect creates a perfect unity of space with contrasting colors that puts together, and takes this type of work with the color from his worldview. In his worldview while the universe has opposites, day and night, white and black, and love and hatred exist together.

\section{DECORATIVE CORNICE OF APSES}

Many assertions about the value and importance of writing and calligraphy have often been said and for the cause of Muslims' attention to written inscription this point will suffice to say that the miracle of Islam is manifested on the writing at all ages. For a Muslim to pray against the images and shapes is averse. For this purpose, questions have been asked from the Imams (AS) on the writing and stencils that we mention two of them. Someone asked Imam Musa bin Ja'far (AS) about praying in a mosque that something of Qoran or mention of God has been written in the direction of Qibla, Jesus replies: "No problem."

\section{THE RELATIONSHIP BETWEEN NOMADIC SALTSHAKER OF IRAN AND THE MOTIFS OF APSE AND REFLECT SIMILAR MOTIFS TO IT ON A VARIETY OF BAKHTIARI BALES}

A lot of ideas have been published about how the emergence of this type of Apse. Some have considered it as a conception of the view of animal skin which was the first ground cloth of human and some have likened it to the caves entrance of the early human settlement. Of course, the truth lies beyond all these assumptions and such a fundamental form has a root older than the Apse of mosques. But this fact cannot be denied that Mihrab carpet or its figure on the carpet in the Islamic civilization reached its peak fertility.

\section{MIHRABI CARPETS}

The figure of Apse inspired designers in creating this design. Sometimes the Apse context is woven simple and without design and sometimes covered with foliage and Shah-Abbasi flowers and sometimes depicting the design of tree. Mihrabi map according to the columns holding arches are used in its decoration or a Qandil hanging from a vault of the Apse

\section{COLUMNED MIHRABI DESIGN}

In such a mihrabi rugs, aside from the essential component of design that is the Apse and its high curved form another element is seen which is two pillars that form the base of the Apse, these pillars can have certain concepts, as we know, each building is based on the foundations and pillars and any damage on this basis can lead to the destruction of the building.

\section{QANDIL MIHRABI DESIGN}

In such a mihrabi rug the design of Qandil is to decorate that has a symbolic relation with the entire building of mosque. Basically, Qandil does not hang in the mosque's Apse, but the researchers have wrote on this design in Apses and tiling of the Apses in 7th and 8th century AD

\section{TREE MIHRABI DESIGN}


Tree is another element that has an indisputable religious value and its origins are very old, often we see the design of this tree in the area that surrounded by the Apse (the Holy arch faced) carpets for prayer.

\section{GOLDANI MIHRABI DESIGN}

In these mihrabi rugs, except the Apse which is the main format of design, another important element complete it and it is a pot is usually designed individually from the bottom of the rug and foliage, flowers and plants that derive from it with mazes to the top of arch of the Apse adorned the design. At the top of the pot a Qandil is usually hung from the Apse and in some cases the Qandil is hung like a reverse pot that emitted foliage is from a point source.

\section{PERSPECTIVE MIHRABI DESIGN}

In these plans, we see an Apse which is as a window to a view of nature, in fact this is illusory nature of paradise, and this is what the artist gives objectivity to his mental images of the promised paradise and gives material form to it to induce the viewer that to reach Paradise steps should be taken and thus prove the existence of Paradise.

\section{SAJJADEHIE DESIGN (DESIGN OF SAJJADEH SHAH ABBASI)}

It is a design of a rug that usually the verses of Quran are woven in the upper half of it and its general form is as a design of the Apse. The normal size of the rug is considered so that a person can easily pray on it. In this design any longitudinal parts of carpet is repetitive and symmetry.

\section{THE DIFFERENCE BETWEEN SAJJADEHIE DESIGN RUGS WITH SAJJADEHIE RUGS}

The word Sajjadeh, which often confuse it with two rug carpet, indicates a carpet that its size is somewhat smaller. According Karapask: this word derives from "Sajjadeh" it means "one who bends to pray." Thus the word reminds the religious use of these carpets. The Persian words Namazeh, still better than the previous, indicates the religious use of these carpets, because Namazeh accurately represent the prayer rug.

\section{HEZAR GOL MIHRABI DESIGN (DIAPER)}

It is a compound and fundamental design derived from the main Mihrabi design that the soffit of altar is covered with colorful flowers. It is in fact, forms that as chain surround around Toranj and Lachak, separate them from the context of carpet. This term is common in Khorasan. In this area, the Eslimi branches, flowers stem and leaves, the lines that connect the flowers are called "rope". Such floral designs have been observed in Iranian and Anatolian prayer rugs in the tenth century AH and Indian prayer rugs "Noghal."

\section{BAGHI MIHRABI DESIGN (MIHRABI CHAHARBAGH)}

A design based on which the carpet weaving was flourished at the time of "Safavid". In this design, from the two axes of garden, the main axis is longer than the other axis that is the minor axis. These axes indicate the two water streams that in confluence with each other divide the context to the four parts and this is the Iranian ancient design which is the geometrical basis for designing the Iranian garden, which comes from ancient Asian philosophy based on which the universe is divided into four parts that four large rivers separate it from each other.

\section{GONBADI MIHRABI DESIGN (DOMED)}

In some carpets, the Mihrab design has changed to the form of mosques' dome and evokes another holy place for viewer, artists with integration or isolation of his findings from around, changes his creativity to new art form, and this shows the creative mind of designer which is a compilation of the dome and the altar. Here the designer creates a new design in Mihrabi carpets which is different from other Mihrabi designs and can be named Gonbadi Mihrabi design or domed Mihrabi.

\section{TORANJ MIHRAB DESIGN (MEDALLION)}

As is common, we see Toranj in carpets Lachak and Toranj that the main theme of design in these rugs is Lachak and Toranj. In Toranj Mihrabi design the motif design of Lachak, to the two width of carpet, gives a mode like "altar" that in some of these carpets a Qandil that hung from the top of the altar is bigger than its usual size and shows itsef in the shape of a 
Toranj in the field. Generally, these carpets are in the category of mihrabi carpets but is known as medallion mihrabi (Toranj Qandil).

\section{PICTORIAL MIHRABI DESIGN (WITH PICTURES)}

There is a small group of mihrabi carpets named Pictorial mihrabi carpets, weaving these carpets (Pictorial carpets) became common in Iran from the thirteenth century and in these designs the images of religious figures or the kings of that period were used under the altar. That the mihrabi design in these rugs is a kind of frame which surrounds the basic design (picture). Because, in terms of religion the existence of images of human beings and animals on the prayer rugs is not correct, and these carpets are purely decorative.

\section{NAZEM DESIGN}

Nazem design is a design and painting is very old and well known that from the Safavid period, with the name Goldani design in almost all carpet weaving cities of Iran as well as India was woven in different ways and in Qashqaie tribe also about two centuries ago continuously and exclusively was woven by weavers of Kashkouli tribe. Most western carpet experts and art experts from Professor Pope to other famous collectors such as Joseph McMullan have brought it among prayer rugs without note the prayer rug is not conventional among nomadic tribes of Fars and especially the inappropriate and non-prayer rug size of these rugs which are often double and sometimes triple the prayer rug.

\section{SYMBOL IN THE CARPET}

Art is eternal because the symbols used in them have a large number of meanings and speak for all languages by the symbolic language, as you know, human understanding of the world around him is a symbolic recognition and in the world today, the symbol is a kind of sign language. Jung says: When human has difficulty to inclusion of some concepts in signs, appeals to the symbol, because symbol increases his expressive power. Each symbol has two meanings; one shows itself as appearance and the other hidden, which needs more investigations. Images that human was created is not a purely material world, but is a world full of symbols that are valuable to him.

\section{CYPRESS SYMBOL}

The design on cashmere shawls and Ghalamkari of Isfahan, is like a Cypress that its tip is bent by the wind, and this implies that from ancient times, people are paying special attention to this tree. Upright Cypress for the above reasons, like Mourd and Sodab and houm was holy and for a long time, was the Iranian special mark, which according to Persian tradition, Zoroaster brought this tree from the heaven, and planed it in the front of the fire temple. One of these events is undoubtedly the story of Kashmar cypress, a cypress that cutting it caused a great tragedy in Iranian culture and literature. This Cypress was planted by Zoroastrian. According to tradition, the prophet Zoroaster in his life planted two Cypress with his hand to fortune of Saad. One, Farumad Cypress and the other Kashmar Cypress, these two Cypress were so high and thick that visiting them was a surprise to everyone. Abbasid caliph al-Mutawakkil who had heard the description of these Cypress, ordered to cut the Kashmar cypress and take it to him in Samereh

\section{SHAJAR AL-AKHZAR SYMBOL}

The Holy Qur'an speak of two green trees that the fire has been kindled by it: the first (AlQasas verse 30) in connection with the story of Moses that in Wadi e Aiman, fire from jujube tree and according to some traditions of the jujube tree, was appeared on the Prophet and came out a voice from it that "O Moses, I am God, Lord of the Worlds". In ancient medical books many medical properties have listed for jujube tree. Iqbal Lahori Iqbal Lahori has mentioned this tree, "Palm Sina".

\section{ANALYSIS OF THE RESULTS}

The opinions expressed by the authors have no contradiction with each other that have been dragged from the Mehrabeh to churches and mosques. Overall, the study shows us that the form of altar is sacred to people of all courses so that in Mehrabeh, mosques and even in miniatures has been used. With more accuracy to Iranian miniatures, we realize that the main theme of paintings is always under the altar or altar-like form which is displayed with hills or other visual elements.

\section{SUGGESTION}


Given the little history of this study and the absence of necessary research, it is suggested to the officials and stakeholders of the country's carpet to provide the Statistics of mihrab carpets in different museums in the world, and register their designs, to be able to investigate the evolution and transformation of this symbolic map in the years.

\section{REFERENCES}

Hosouri, Ali. "Principles of traditional design in Iran", published by Cheshmeh, Tehran, first, 1381, pp. 9 and 11

Zaviye, Sayed Said. " Collect and record system of the Iranian carpet designs» Roundtable on the issues of Iran's Handmade Carpet, carpets and handicrafts and rural Administration, 1375 , pp. 35 to 43

«culture of Handmade Carpet" Iranian National Standard No. 1460, second printing, Persian date Khordad 1371

Edwards, Sicil. "Iranian carpets", publishing Farhangsara, Second printing, 1368

Daryaei, Nazila. 'Essay the Design and Myth in Iran's Handmade Carpet", Proceedings of the first National Research Seminar on Handmade carpet, Tehran, Volume II, Persian date mehr 1382

sajadi, Ali. "The evolution of the altar" in Islamic architecture of Iran from the beginning to the Mongol invasion, Tehran Cultural Heritage, first edition, 1375, pp. 44 and 45

Moein, Mohammad. "Persian culture", Eighth Edition, 1371, published by Amir Kabir, 3900 and 3901

sajadi, Ali. "The evolution of the altar", ..., p. 46

Touraj, Zhuleh. "A Study in Iranian carpet" Yasavoli Publications, Tehran, 1381, Page 43

Halen Brand, Robert. "Islamic Architecture" (form, function means), translate Bagher Ayatollah Zadeh Shirazi, published by Rozaneh, first edition, 1380, p. 45

Erfan, Mohammad Hadi. " A series of studies on the architecture of the mosque," the architecture of the mosque, Volume I, ..., p 275

Halen Brand, Robert. "Islamic Architecture" (form, function means), translate Bagher Ayatollah Zadeh Shirazi, ..., p. 46

Erfan, Mohammad Hadi. " A series of studies on the architecture of the mosque," the architecture of the mosque, Volume I, ..., p 275

Halen Brand, Robert. "Islamic Architecture" (form, function means), translate Bagher Ayatollah Zadeh Shirazi, ..., p. 46

Halen Brand, Robert. "Islamic Architecture" (form, function means), translate Iraj Etesam, ..., p. 83

Prochazka, Amjad Bhomil. "The architecture of Mosques of the world", translation Hussain Sultan Zadeh, Amir Kabir Publications, 1373

Taghizadeh, Mohammad. "Mosque, The dominant body in the Islamic Complex" The architecture of mosques, Volume II, ..., p. 132

Najafi Zyarany, said. "The search for achieving the concepts" The architecture of mosques, Volume II, ..., p. 217

Shekari Neary, Javad. "Explain the architectural characteristics and physical properties and Islamic era mosques sacred art ", ..., p. 244 and 254

Noghreh kar, Abdulmajid. "Architecture of the mosque From Concept to physical," Architecture of the mosque, Volume II, ..., p 235

Erfan, Mohammad Hadi. "A series of studies on the architecture of the mosque," the architecture of the mosque, Volume I, ..., p 279

Nasiri, Mohammad Javad. "Siri art of carpet weaving in Iran," Tehran, Winter 1374, author, page 78

Yasavoli Javad., "An Introduction to Understanding Iranian carpet", the cultural center, Tehran, Second Edition, 1375, p 132

Nasiri, Mohammad Javad. " Passing in the art of carpet weaving in Iran," Tehran, Winter 1374, author, page 78 
Yasavoli Javad., "An Introduction to Understanding Iranian carpet", the cultural center, Tehran, Second Edition, 1375, p 132

Hangldin, Armen. "Iranian carpets" (tools and materials, records of designs, textures practices), translation Asghar. Karimi, cultural center, first edition, 1375, p 32

Mohammad Zaki, Mohammad Hassan. "Art of Iran in the Islamic era", translation Mohammad Ibrahim Eghlidi, contemporary sound, Tehran, First Edition, 1377, p. 144

Daneshgar Ahmed. "Memorial Carpet comprehensive culture ", ..., p. 119

Hangldin, Armen. "Iranian carpets" (tools and materials, records of designs, textures practices), translation Asghar. Karimi, cultural center, first edition, 1375, p 25

Ferreira, R.W. "Iranian arts", translation Parviz Marzban, Forouzanfar, first edition, 1374, p. 134

Parham, Sirus. "Masterpieces of Fars' carpet", Soroush, Tehran, first edition, 1375, pp. 25 to 27

Azarpad, Hassan - heshmati Razavi, fazlollah "Farshnameh Iran," Research Institute, first edition,1372, p. 100

Halen Brand, Robert. "Islamic Architecture" (form, function means), translation Iraj Etesam, ..., p. 97

Yahaghi, Mohammad Jafar. "Culture of mythology and references story in Persian literature", Institute for Humanities and Cultural Studies of the Ministry of Culture and Higher Education and Soroush, Tehran, 1375, pp. 134 and 135

Tanavoli, Parviz. " Cypress of Zarathustra" Peacock (Quarterly Iranian art), first year, No. 3 and 4 , the spring and summer of 79 , pp. 53 and 54 